\title{
Appendectomy in Pediatrics the Value of Peritoneal Fluid Smear and Its Bacteriological Profile
}

\author{
Manal Mohammed Kadhim \\ Department of Medical Microbiology \& Clinical Immunology, College of Medicine, Al-Qadisiya University, Diwaniya, Iraq \\ Email:mic_drmanal@yahoo.in
}

Received October 1, 2012; revised November 9, 2012; accepted November 19, 2012

\begin{abstract}
Introduction: Acute appendicitis is the most common cause of abdominal pain requiring surgery in children. In most instances the infecting organisms are normal inhabitants of the lumen of appendix. Surgery allows easy microbiological sampling. Aspiration of fluid or pus in a syringe is preferred. Swabs are less suitable and only to be used when sampling with a syringe is not feasible. Antimicrobial susceptibility testing of the isolated bacteria and particularly of the anaerobes can be important to adjust therapy in case of the presence of multi resistant bacteria. Objective: The aim of the study was to determine the bacteriological profile of acute appendicitis in children. Materials and Methods: Study design is a prospective descriptive study including children hospitalized for acute appendicitis. Tissue samples (a specimen of the appendix), peritoneal fluid swab from the appendicial fossa and the peritoneal exudates (if exists) obtained at surgery from 54 children with suspected acute appendicitis operated at the pediatric surgery unit at the Maternity and Child Teaching Hospital in Al-Qadisiya province from the period 1st of June 2007 to the end of May 2011, were examined histologically and by culture for aerobic and anaerobic bacteria. Results: Out of these, 39 boys (72.2\%) and 15 $(27.7 \%$ girls). Their age ranged between $(1.8-13)$ years, with a mean of 6.9 years. Of the all patients studied 34 presented with suppurative and phlegmnous appendicitis, 8 with gangrenous appendicitis, 6 with septic complications of appendicitis and 6 had normal appendices. Only 80 of the 108 swabs taken yielded a positive culture (74.07\%). Conclusion: Although in our study no antibiotic regime was changed on the basis of a positive culture swab and the peritoneal culture swabs do not improve immediate postoperative therapy based on surgical impression and rapid histological reporting, however, the routine use of peritoneal culture swabs may be of value in identifying patients requiring outpatient follow-up.
\end{abstract}

Keywords: Appendectomy; Pediatrics; Bacteriological Profile

\section{Introduction}

Acute appendicitis is the most common cause of abdominal pain requiring surgery in children. But it is an uncommon entity in young children and rare in infants. The classic description of appendicitis includes the onset of periumbilical pain followed by nausea, then migration of pain to the right lower quadrant (RLQ) and finally, vomiting and fever. However, this progression of symptoms is less common in children than adults [1]. Absence of classic symptoms leads to a higher rate of appendiceal perforation in children. Pathogenesis of appendicitis is still uncertain, its significance in septic complications of appendicitis is well established $[2,3]$.

The exact cause remains unclear, but luminal obstructtion, diet, and familial factors have been suggested, and the etiology may be multifactorial in some cases $[4,5]$. Some bacteria and parasites were found in histopathological evaluations of the appendices [6]. Inflammation of the appendix ranges from minor, simple acute inflamma- tion to suppurative necrosis and perforation, but in some appendectomized patients it could be histologically classified as normal appendices.

Most workers have found the qualitative flora of appendicitis does not differ appreciably from that of the normal appendix in adults and children [3]. Both Streptococcus milleri and Bacteroides fragilis, however, have been implicated in the pathogenesis of appendicitis by increased isolation rates in acute inflammation $[7,8]$. Less is known of the quantitative flora of the acutely inflamed and normal appendix. In adults anaerobic bacteria are more commonly found in counts of above $10^{6}$ colony forming units $/ \mathrm{ml}$ than aerobic bacteria in acute inflammation, and anaerobic bacteria, in particular bacteroides species, have been quantified in acutely inflamed and normal appendices. Cultures from inflamed appendices usually revealed that there is a hardly pyogenic organism. The most common organisms are a mixture of Escherichia coli (85\%), entercocci (30\%), nonhaemolytic strep- 
tococci, anaeropic streptococci together with clostridium welchii $(30 \%)$ and bacteroides [9,10]. In most instances the infecting organisms are normal inhabitants of the lumen of appendix. Surgery allows easy microbiological sampling. Aspiration of fluid or pus in a syringe is preferred. Swabs are less suitable and only to be used when sampling with a syringe is not feasible. For anaerobic culture, special precautions should be taken to expel air bubbles after aspiration. Gram-staining and aerobic and anaerobic culture of pus is generally advocated. Blood cultures are also advised: generally two to three sets of an aerobic plus anaerobic bottle are obtained with 10 - 30 min interval. Antimicrobial susceptibility testing of the isolated bacteria and particularly of the anaerobes can be important to adjust therapy in case of the presence of multi resistant bacteria [11].

\section{Objective}

The aim of the study was to determine the bacteriological profile of acute appendicitis in children and determining the influence of microbiological results on postoperative outcome in patients undergoing appendicectomy.

\section{Materials and Methods}

Study design is a prospective descriptive study including children hospitalized for acute appendicitis. Tissue samples (a specimen of the appendix), peritoneal fluid swab from the appendicial fossa and the peritoneal exudates (if exists) obtained at surgery from 54 children with suspected acute appendicitis operated at the pediatric surgery unit at the Maternity and Child Teaching Hospital in Al-Qadisiya province from the period 1st of June 2007 to the end of May 2011, were examined histologically and by culture for aerobic and anaerobic bacteria. After histology evaluation, patients were classified depending on the severity of inflammation into Suppurative and phlegmnous, Gangrenous, Septic and non-appendicitis (or normal histology) subgroups. All intra-operative microbiological swabs were taken using two microbiological swab supplemented with amie's and charcoal transport medium, and then immediately plated onto aerobic and anaerobic culture. For each specimen, the following anaerobic bacteriologic media were inoculated: brucella blood agar, Bacteroides bile esculin agar, phenylethyl alcohol blood agar, and sheep blood with kanamycin and vancomycin agar plates, and thioglycollate broth. Anaerobic plates were incubated in an incubator placed inside the anaerobic chamber (atmosphere, 10\% carbon dioxide) at $35^{\circ} \mathrm{C}$. Aerobic media included trypticase soy sheep blood agar, Columbia colistin-nalidixic acid agar, and chocolate agar plates (incubated in 5\% $\mathrm{CO}_{2}$ ) and MacConkey agar plates (incubated in air). Fluid specimens were inoculated directly $(0.05 \mathrm{~mL}$ per medium $)$, and tissues were emulsified in $1.0 \mathrm{~mL}$ of thioglycollate broth and inoculated to media $(0.05 \mathrm{~mL}$ in to solid media and the remainder into the thioglycollate). Plates were streaked in a standardized quadrant format to facilitate enumeration of colonies [12]. Gram stains of all specimens were examined, and the plates were examined after $1,2,5$, and 10 days of incubation. The thioglycollate broths were subcultured, and isolates were identified only if no growth occurred on primary plates. All organisms were identified according to standard methods outlined in the Wadsworth Anaerobic Bacteriology Manual and Bailey \& Scott's Diagnostic Microbiology [12,13]. Antibiotic susceptibilities of bacterial isolates were determined using the disk-diffusion method, according to the actual recommendations. The susceptibilities of aerobic and anaerobic bacteria were determined for antibiotics ciprofloxacin, ampicilin, trimethoprim/Sulfamethoxazole, gentamicin, amikacin, cefotaxime, ceftriaxone, imipenem, clindamicyn, vancomycin, carbenicillin, chloramphenicol, metronidazole, and tetracycline. Bacteria were enumerated semiquantitatively as follows: growth in the original inoculum area only, 1+; growth over the first half of the plate, 2+; growth extending to the third quadrant, $3+$; and growth extending throughout all areas of the plate, $4+$. Significance of differences between groups was determined using $\mathrm{x} 2$-test analysis and two-tailed z-tests. $P<$ 0.05 was considered statistically significant, and all reported $P$-values were two-tailed. Consent forms were signed by all the parents for all the patients underwent this study for academic and ethical considerations.

\section{Results}

During the study period, 54 children were operated with clinical evidence of acute appendicitis .Out of these, 39 $(72.2 \%)$ boys and $15(27.7 \%)$ girls. Their age ranged between $(1.8-13)$ years, with a mean of 6.9 years. Of the all patients studied 34 (60.71) presented with suppurative and phlegmnous appendicitis, 8 (14.28) with gangrenous appendicitis, 6 (10.71) with septic complications of appendicitis and 6 (10.71) had normal appendices. Overall, an intra-operative swab was taken in the patients, including those with normal appendices although swabs were taken more frequently in patients with "complicated" appendicitis. Only 80 of the 108 swabs taken yielded a positive culture $(74.07 \%)$. The proportion of patients with a positive culture, rang of types and semiquantitive counts of isolates increased with severity of histological diagnosis, Tables 1 and 2. The bacterial species isolated from appendices and appendix related infections (Table 3). Anaerobes were more frequently isolated than aerobes and members of the Bacteroide spp. group were predominant. Polymicrobial infection was found in most of cases. Gram-negative bacilli were the most 
Table 1. Frequency distribution of patients included in the study according to histopathology profile and positivity of culture.

\begin{tabular}{|c|c|c|c|c|c|}
\hline \multirow[t]{2}{*}{ Histopathology } & \multicolumn{2}{|c|}{$\begin{array}{c}\text { Patient } \\
\text { included in } \\
\text { the study }\end{array}$} & \multirow{2}{*}{$\begin{array}{c}\text { Total smear } \\
\text { (appendiceal } \\
\text { tissue and } \\
\text { peritoneal } \\
\text { fluid) }\end{array}$} & \multicolumn{2}{|c|}{$\begin{array}{l}\text { Positive } \\
\text { culture }\end{array}$} \\
\hline & NO. & $(\%)$ & & NO. & $(\%)$ \\
\hline $\begin{array}{l}\text { Suppurative } \\
\text { and } \\
\text { phlegmnous }\end{array}$ & 34 & 60.71 & 68 & 56 & 82.35 \\
\hline Gangrenous & 8 & 14.28 & 16 & 12 & 75 \\
\hline Septic & 6 & 10.71 & 12 & $11^{*}$ & 91.66 \\
\hline Normal & 6 & 10.71 & 12 & 1 & 8.33 \\
\hline Total & 54 & 100 & 108 & 80 & 74.07 \\
\hline
\end{tabular}

${ }^{*} P<0.0001\{$ Complex (septic) vs. normal\}.

frequently isolated microorganisms among the aerobic bacteria with the predominant of Escherichia coli and Klebsiella pneumoniue. There were no significant differences in the proportions of different genera found among the four patient groups. The counts of the isolated organisms showed no significant differences within individual appendices $(P>0.05)$. Between normal and in- flamed appendices there was no significant difference in the counts of all isolates $(0.05<P<0.1)$, We also observed differences in the number of organisms recovered between specimens of perforated appendices and those of gangrenous appendices: cultures of the peritoneal fluid were almost always positive for bacteria in cases of perforating appendicitis, whereas in cases of gangrenous appendicitis, fluid cultures were usually negative for pathogens but tissue cultures were positive. Table 3 shows that bacteroides species and E. coli were the predominant organisms in most normal and acutely inflamed appendices. Aerobic bacteria were highly sensible to imipenem, amikacin, ceftriaxone clindamicyn, but it was absolutely resistance to ampicillin. For anaerobic bacteria, sensitivity rates from high to low were chloramphenicol, carbenicillin, metronidazole and clindamycin (Table 4).

There was no significant difference in the power of surgical or histological assessment of the appendicitis at predicting a positive peritoneal culture result. Complex appendicitis was more likely to be associated with a positive peritoneal culture $(P<0.0001)$.

\section{Discussion}

Appendicitis is one of the most common and costly acute

Table 2. Enumeration of types and semi quantitative counts of isolated organisms in relation to histopathology results were available for evaluation.

\begin{tabular}{|c|c|c|c|}
\hline $\begin{array}{l}\text { No. of patients with indicated type of } \\
\text { appendicitis from whom both specimens } \\
\text { were available }\end{array}$ & Appendiceal tissue & Peritoneal fluid & $\begin{array}{l}\text { Semi-quantitative } \\
\text { counts of isolates } \\
\text { per specimen }\end{array}$ \\
\hline \multicolumn{4}{|c|}{ Suppurative and phlegmnous } \\
\hline 10 & Growth (one isolates per specimen & No growth & $1+$ \\
\hline 9 & Growth (one isolates per specimen & Growth (one isolates per specimen & $1+$ \\
\hline 5 & Growth ( one isolate per specimen) & $\begin{array}{l}\text { Growth }(1-2 \text { isolates } \\
\text { per specimen })\end{array}$ & $1+$ \\
\hline 4 & Growth ( 2 isolates per specimen) & Growth (one isolates per specimen) & $2+$ \\
\hline 4 & Growth ( 1 isolates per specimen) & Growth ( 2 isolates per specimen) & $2+$ \\
\hline 2 & No growth & Growth ( 2 isolates per specimen) & $1+$ \\
\hline \multicolumn{4}{|c|}{ Gangrenous } \\
\hline 1 & Growth ( 3 isolates per specimen) & Growth ( 3 isolates per specimen) & $2+$ \\
\hline 1 & Growth ( 2 isolates per specimen) & Growth (one isolates per specimen) & $3+$ \\
\hline 6 & Growth (2 - 3 isolate per specimen) & No growth & $2+$ \\
\hline \multicolumn{4}{|c|}{ Septic } \\
\hline 5 & Growth (2 - 6 isolates per specimen) & $\begin{array}{c}\text { Growth }(3-5 \text { isolates per } \\
\text { specimen })\end{array}$ & $4+$ \\
\hline 1 & No growth & $\begin{array}{c}\text { Growth }(2-6 \text { isolates per } \\
\text { specimen })\end{array}$ & $4+$ \\
\hline \multicolumn{4}{|c|}{ Normal } \\
\hline 1 & No growth & Growth ( 2 isolates per specimen) & $1+$ \\
\hline 5 & No growth & No growth & - \\
\hline
\end{tabular}


abdominal illnesses associated with inflammation [14]. In this study we investigated patients with acute appendicitis as well as patients with normal appendices and with septic complications of appendicitis. Both aerobic and anaerobic bacteria were isolated from all groups of patients, though in varied proportions. Since the microbial etiology of appendicitis was described in 1938, it has served as the prototype of mixed aerobic and anaerobic intra abdominal infections [15]. Whereas Altemeier's original investigations demonstrated mixed flora in patients with complicated appendicitis, subsequent studies have also documented mixed flora in patients with acute suppurative appendicitis $[15,16]$. However, investigators in these studies did not rigidly distinguish between acute and complicated appendicitis on the basis of pathology, a distinction which has made comparison of the bacteria encountered in each of these conditions difficult. In our study, E. coli was the most frequently encountered aerobic bacteria, similar with previous reports of children with gangrenous and perforated appendicitis [17,18]. Perforated appendicitis was responsible for the majority of

Table 3. Organisms isolated from both appendiceal tissue and peritoneal fluid specimens according to histological profile.

\begin{tabular}{|c|c|c|c|c|c|}
\hline $\begin{array}{l}\text { Bacterial } \\
\text { species }\end{array}$ & $\begin{array}{l}\text { Suppurative and C } \\
\text { phlegmnous ( } 34)\end{array}$ & $\begin{array}{l}\text { Gangrenous } \\
\text { (8) }\end{array}$ & $\begin{array}{l}\text { Septic } \\
(6)\end{array}$ & $\begin{array}{l}\text { Normal } \\
\text { (6) }\end{array}$ & $\begin{array}{l}\text { Total } \\
(54)\end{array}$ \\
\hline \multicolumn{6}{|c|}{ Anaerobes } \\
\hline Bacteroide spp. & 28 & 7 & 11 & 1 & 47 \\
\hline $\begin{array}{l}\text { Fusobacterium } \\
\text { spp. }\end{array}$ & 0 & 1 & 1 & 0 & 2 \\
\hline Veillonella spp. & 1 & 0 & 1 & 0 & 2 \\
\hline $\begin{array}{l}\text { Clostridium } \\
\text { perfringens }\end{array}$ & 1 & 2 & 1 & 0 & 4 \\
\hline Peptococcus spp. & 0 & 0 & 1 & 0 & 1 \\
\hline $\begin{array}{l}\text { Peptostreptococcus } \\
\text { spp. }\end{array}$ & 0 & 2 & 1 & 0 & 3 \\
\hline Total & 30 & 12 & 16 & 1 & 59 \\
\hline \multicolumn{6}{|c|}{ Aerobes } \\
\hline Escherichia coli & 11 & 5 & 6 & 1 & 24 \\
\hline $\begin{array}{l}\text { Klebsiella } \\
\text { pneumoniae }\end{array}$ & 4 & 2 & 4 & 0 & 9 \\
\hline Citrobacter freundi & 0 & 1 & 2 & 0 & 3 \\
\hline $\begin{array}{c}\text { Enterobacter } \\
\text { cloacae }\end{array}$ & 0 & 1 & 2 & 0 & 3 \\
\hline Proteus spp. & 0 & 0 & 1 & 0 & 1 \\
\hline Pseudomonas spp. & 1 & 1 & 2 & 1 & 5 \\
\hline Streptococcus spp. & 0 & 1 & 1 & 0 & 2 \\
\hline $\begin{array}{l}\text { Staphylococcus } \\
\text { spp. }\end{array}$ & 0 & 0 & 3 & 0 & 5 \\
\hline Total & 16 & 11 & 25 & 1 & 43 \\
\hline
\end{tabular}

Table 4. Antibiotic susceptibility pattern for aerobic and anaerobic bacteria which were isolated from both appendiceal tissue and peritoneal fluid specimens.

\begin{tabular}{|c|c|c|}
\hline Antibiotics & $\begin{array}{c}\text { Susceptible } \\
(\%)\end{array}$ & Resistance (\%) \\
\hline \multicolumn{3}{|c|}{ Aerobic isolates } \\
\hline Ampicilin & $15 \%$ & $85 \%$ \\
\hline Ciprofloxacin & $76 \%$ & $24 \%$ \\
\hline Gentamicin & $45 \%$ & $55 \%$ \\
\hline Amikacin & $84 \%$ & $16 \%$ \\
\hline Cefotaxime & $80 \%$ & $20 \%$ \\
\hline Ceftriaxone & $80 \%$ & $20 \%$ \\
\hline Imipenem & $100 \%$ & Zero \\
\hline Clindamicyn & $95 \%$ & $5 \%$ \\
\hline Vancomycin & $85 \%$ & $15 \%$ \\
\hline $\begin{array}{c}\text { Trimethoprim/ } \\
\text { Sulfamethoxazole }\end{array}$ & $79 \%$ & $21 \%$ \\
\hline \multicolumn{3}{|c|}{ Anaerobic isolates } \\
\hline Carbenicillin & $92 \%$ & $8 \%$ \\
\hline Cefoxitin & $55 \%$ & $45 \%$ \\
\hline Cefotaxime & $55 \%$ & $45 \%$ \\
\hline Clindamycin & $72 \%$ & $28 \%$ \\
\hline Chloramphenicol & 100 & Zero \\
\hline Metronidazole & $86 \%$ & $14 \%$ \\
\hline Tetracycline & $35 \%$ & $65 \%$ \\
\hline
\end{tabular}

secondary bacterial peritonitis found in our study. Alexander noticed that between one third and three quarters of children present with perforated appendicitis at the time of diagnosis depending on age [17]. There was little difference in the incidence of Bacteroides species in the various lesions except in patients with a perforated appendix where these organisms were found in most of the swabs. There are several issues regarding the importance of certain microorganisms isolated in secondary peritonitis. Although enterococci are frequently isolated as part of a polymicrobial intra-abdominal infection, their role as pathogens and the need for antibiotic coverage specifically toward this organism remains unclear in a review of several trials [19].

Bacteroides are anaerobic Gram-negative bacilli which are relatively difficult to isolate in the routine laboratory without special precautions [20]. Care must be taken in the collection of the swab and it must be delivered to the laboratory in special anaerobic transport media. It is necessary to use special selective culture media to allow easy identification, and blood agar containing neomycin $0.01 \%$ is commonly used. It has been shown that using these precautions the rate of isolation can be significantly increased [21]. The shift from histologically normal toward gangrenous appendices was clearly associated with 
markedly elevated anaerobic bacterial counts in terms of species. Bacteriod fragilis is the most frequent anaerobic species found in acute appendicitis. Nonetheless Bacteriod fragilis is the most common isolate [22]. It is evident that some bacteria may pass the intact appendiceal wall prior to perforation, while progressive infection and subsequent tissue damage with necrosis allows bacteria to move in to peritoneal cavity [22]. And here we must remember most of the bacteria that are implicated in intra-abdominal infections originate from the normal intestinal flora. With the exception of Bacteroides spp., most other anaerobes are never encountered in pathology but they are our main barrier against colonization and infection by pathogens. This colonization barrier is particularly sensitive to different factors like antimicrobial treatments [11]. The longer the duration of peritonitis, the more anaerobes become present [23]. Although this study is too small to draw any definite conclusions, it is felt that Bacteroides should be considered an important pathogen in appendicitis and should be taken into account in the few ill patients where antibiotic treatment is contemplated. It was also noted that swabs taken from the surface of the appendix itself were more often positive than those from the peritoneal cavity, and this difference appears to be significant. It is important that the chemotherapy of post appendicectomy infections include an antibiotic active against Bacteroides.

The debate remains open concerning the role of Pseudomonas aeruginosa in perforated appendicitis. Pseudomonas aeruginosa has been reported in previously healthy children in several studies [24-28] and even in $20 \%$ of young adults without co-morbidities in one study. In one pediatric study $P$. aeruginosa was isolated in up to $42 \%$ of peritoneal pus [28]. Two retrospective open (nonrandomized) studies comparing different antibiotic regimens have found an increased complication rate in the group without antipseudomonal coverage. However, $P$. aeruginosa was often co-cultured with anaerobes [29]. In a retrospective study performed in a Belgian pediatric hospital, $23 \%$ of the children with peritonitis had $P$. aeruginosa in their peritoneal fluid. The presence of $P$. aeruginosa was correlated with an increased surgical complication rate, independently from the presence of anaerobes [30]. No prospective large trial has evaluated the role of Pseudomonas aeruginosa in patients (particularly children) with complicated appendicitis.

All studies questioning the use of intra-peritoneal swabs were open, non-randomized, and retrospective with incompletely matched control groups, non-standardized swab collection techniques, and consequently lacked power to inform surgical practice. They concluded that an appropriately powered randomized, blinded, prospective, controlled clinical trial is needed to test for absolute efficacy in the use of peritoneal swabs in patient man- agement. Until controlled trial data becomes available, it may be wise to continue peritoneal swabs at least in high-risk patients to decrease clinical and medico legal risk [31].

\section{Conclusion}

Although in our study no antibiotic regime was changed on the basis of a positive culture swab and the peritoneal culture swabs do not improve immediate postoperative therapy based on surgical impression and rapid histological reporting, however, the routine use of peritoneal culture swabs may be of value in identifying patients requiring outpatient follow-up and Empiric antibiotic therapy in acute complicated appendicitis in children should be efficient against microorganisms were isolated.

\section{REFERENCES}

[1] T. Becker, A. Kharbanda and R. Bachur, "Atypical Clinical Features of Pediatric Appendicitis," Academic Emergency Medicine, Vol. 14, No. 2, 2007, pp. 124-129. doi:10.1197/j.aem.2006.08.009

[2] B. Andersen, A. Bendtsen, L. Holbraad and A. Schantz, "Wound Infections after Appendicectomy," Acta Chirurgica Scandinavica, Vol. 138, No. 5, 1972, pp. 531-536.

[3] K. M. Elhag, M. H. Alwan, M. S. Al-Adnani and R. A. Sherif, "Bacteroides fragilis Is a Silent Pathogen in Acute Appendicitis," Journal of Medical Microbiology, Vol. 21, No. 3, 1986, pp. 245-249. doi:10.1099/00222615-21-3-245

[4] J. Simpson and J. H. Scholefield, "Acute Appendicitis," Surgery, Vol. 26, No. 3, 2008, pp. 108-112. doi:10.1016/j.mpsur.2008.01.003

[5] I. Dalal, E. Somekh, A. Bilker-Reich, et al., "Serum and Peritoneal Inflammatory Mediators in Children with Suspected Acute Appendicitis," Archives of Surgery, Vol. 140, No. 2, 2005, pp. 169-173. doi:10.1001/archsurg.140.2.169

[6] E. Adehossi and P. H. Parola, "Schistosomal Appendicitis," The Lancet Infectious Diseases, Vol. 4, No. 8, 2004, p. 498. doi:10.1016/S1473-3099(04)01104-1

[7] P. M. Poolc and G. Wilson, "Streptococcus milleri in the Appendix," Journal of Clinical Pathology, Vol. 30, No. 10, 1977, pp. 937-942.

[8] H. Werner, H. Kunstek-Santos, C. Schockermohlc, et al., "Bacteroides and Appendicitis (Author's Translation)," Pathologial et Microbiologia (Blasel), Vol. 42, No. 2, 1975, pp. 110-118.

[9] N. V. Christou, P. Turgeon, R. Wassef, et al., "Management of Intra-Abdominal Infections: The Case for IntraOperative Cultures and Comprehensive Broad-Spectrum Antibiotic Coverage," Archives of Surgery, Vol. 131, No. 11, 1996, pp. 1193-1201. doi:10.1001/archsurg.1996.01430230075014

[10] J. A. Hopkins, J. C. Lee and S. E. Wilson, "Susceptibility of Intra-Abdominal Isolates at Operation: A Predictor of 
Postoperative Infection," The American Surgeon, Vol. 59, No. 12, 1993, pp. 791-796.

[11] P. F. Laterre, et al., "Antimicrobial Therapy for IntraAbdominal Infections: Guidelines from the Infectious Disease Advisory Board (IDAB)," Acta Chirurgica Belgica, Vol. 106, No. 1, 2006, pp. 2-21.

[12] E. J. Baron and S. M. Finegold, "Bailey \& Scott's Diagnostic Microbiology," 8th Edition, Mosby, St. Louis, 1990.

[13] V. L. Sutter, O. M. Citron, M. A. C. Edelstein and S. M. Finegold, "Wadsworth Anaerobic Bacteriology Manual," 4th Edition, Star Publishing, Belmont, 1985.

[14] J. Simpson and J. H. Scholefield, "Acute Appendicitis," Surgery, Vol. 26, No. 3, 2008, pp. 108-112. doi:10.1016/j.mpsur.2008.01.003

[15] W. A. Altemeier, "The Bacterial Flora of Acute Perforated Appendicitis with Peritonitis: A Bacteriologic Study Based upon One Hundred Cases," Annals of Surgery, Vol. 107, No. 4, 1938, pp. 517-528. doi:10.1097/00000658-193804000-00006

[16] W. Y. Lau, C. H. Teoh-Chan, S. T. Fan, W. C. Yam, K. F. Lau and S. H. Wong, "The Bacteriology and Septic Complication of Patients with Appendicitis," Annals of Surgery, Vol. 200, No. 5, 1984, pp. 576-581. doi:10.1097/00000658-198411000-00003

[17] J. R. Campbell and J. S. Bradley, "Peritonitis and IntraAbdominal Abscess," In: S. S. Long, L. K. Pickering and C. G. Prober, Eds., Principles and Practice of Pediatric Infectious Diseases, 2nd Edition, Churchill Livingstone, Philadelphia, 2003, pp. 702-709.

[18] I. Brook, "Microbiology and Management of Abdominal Infections," Digestive Diseases and Sciences, Vol. 53, No. 10, 2008, pp. 2585-2591. doi:10.1007/s10620-007-0194-6

[19] S. Gorbach, "Intra-Abdominal Infections," Clinical Infectious Diseases, Vol. 17, 1993, pp. 261-265.

[20] D. A. Leigh, "The Clinical Significance of Infections Due to Bacteroides fragilis and the Role of Antibiotic Therapy," British Medical Journal, Vol. 3, 1974, pp. 225-228. doi:10.1136/bmj.3.5925.225

[21] K. Hoffmann and F. W. Gierhake, "Postoperative Infection of Wounds by Anaerobes," German Medical Monthly, Vol. 14, No. 1, 1969, pp. 31-33.

[22] I. Jurić, et al., "Frequency of Systemic and Portal Bacteremia in Acute Appendicitis," Pediatrics International, Vol. 43, No. 2, 2001, pp. 152-156. doi:10.1046/j.1442-200x.2001.01360.x
[23] S. H. Dougherty, "Antimicrobial Culture and Susceptibility Testing Has Little Value for Routine Management of Secondary Bacterial Peritonitis," Clinical Infectious Diseases, Vol. 25, Suppl. 2, 1997, pp. S258-S261. doi: $10.1086 / 516241$

[24] A. Arguedas, J. Sifuentes-Osornio, C. Loaiza, et al., "An Open, Multicenter Clinical Trial of Piperacillin/Tazobactam in the Treatment of Pediatric Patients with IntraAbdominal Infections," Journal of Chemotherapy, Vol. 8, No. 2, 1996, pp. 130-136.

[25] M. D. Collins, A. S. Dajania, K. S. Kimk, et al., "Comparison of Ampicillin/Sulbactam plus Aminoglycoside vs. Ampicillin plus Clindamycin plus Aminoglycoside in the Treatment of Intra-Abdominal Infections in Children. The Multicenter Group," Pediatric Infectious Disease Journal, Vol. 17, No. 3, 1998, pp. S15-S18. doi:10.1097/00006454-199803001-00005

[26] H. C. Maltezou, P. Nikolaidis, E. Lebesii, et al., "Piperacillin/Tazobactam versus Cefotaxime plus Metronidazole for Treatment of Children with Intra-Abdominal Infections Requiring Surgery," European Journal of Clinical Microbiology \& Infectious Diseases, Vol. 20, No. 9, 2001, pp. 643-646.

[27] H. K. Goon and P. Sabiha, "Ceftazidime/Metronidazole versus Netilmicin/Metronidazole in the Treatment of Perforated Appendicitis in Children," Clinical Therapeutics, Vol. 12, No. 1, 1990, pp. 54-60.

[28] S. C. Aronoff, M. M. Olson, M. W. Gaudere, et al., "Pseudomonas aeruginosa as a Primary Pathogen in Children with Bacterial Peritonitis," Journal of Pediatric Surgery, Vol. 22, No. 9, 1987, pp. 861-864. doi:10.1016/S0022-3468(87)80656-5

[29] A. E. Yellin, P. N. Heseltine, T. V. Berne, et al., "The Role of Pseudomonas Species in Patients Treated with Ampicillin and Sulbactam for Gangrenous and Perforated Appendicitis," Surgery, Gynecology \& Obstetrics, Vol. 161, No. 4, 1985, pp. 303-307.

[30] N. Schrayen, S. Blumental, M.-H. Delaet, et al., "Pseudomonas aeruginosa in Children's Peritonitis: An Innocent Bystander?" 45th Interscience Conference on Antimicrobial Agents and Chemotherapy (ICAAC), Washington DC, 16-19 December 2005.

[31] H. O. Davies, N. A. Alkhamesi and P. M. Dawson, "Peritoneal Fluid Culture in Appendicitis: Review in Changing Times," International Journal of Surgery, Vol. 8, No. 6, 2010, pp. 426-429. 